\title{
GAMBARAN LINGKUNGAN KERJA, KARAKTERISTIK INDIVIDU DAN STRES KERJA PERAWAT RUMAH SAKIT UMUM AVISENA DI CIMAHI
}

\author{
Hendri Yuliadi \\ Universitas Pendidikan Indonesia \\ hendriyuliadi@student.upi.edu \\ Sumiyati \\ Universitas Pendidikan Indonesia \\ sumiyati@upi.edu \\ Ridwan Purnama \\ Universitas Pendidikan Indonesia \\ ridwanpurnama@upi.edu
}

\begin{abstract}
ABSTRAK
Tujuan - Tujuan penelitian ini adalah untuk mengetahui gambaran lingkungan kerja, karakteristik individu , dan stres kerja.

Desain/metodologi/pendekatan - Desain penelitian ini adalah cross sectional method. Penelitian ini menggunakan pendekatan deskriptif dengan metode explanatory survey. Unit analisis perawat sebanyak 73 orang. Pengumpulan data dengan menggunakan kuisioner. Teknik analisis yang digunakan adalah teknik deskriptif dengan menggunakan distribusi frekuensi.

Temuan - Berdasarkan hasil penelitian mneggunakan analisis deskriptif, didapatkan hasil bahwa lingkungan kerja berkategori cukup kondusif, karakteristik individu berkategori baik dan stres kerja berkategori cukup tinggi.

Orisinalitas/nilai - Perbedaan dalam penelitian ini terletak pada objek penelitian, waktu penelitian, alat ukur, literatur yang digunakan, teori yang digunakan dan hasil penelitian.
\end{abstract}

Kata Kunci: Lingkungan kerja, Karakteristik Individu, Stres Kerja Jenis Artikel: Studi Kasus

\begin{abstract}
Purpose - The purpose of this study is to see the description of work environment, individual characteristics and job stress

Design/methodology/approachh - The design of this study was cross sectional method. This research uses descriptive approach with explanatory survey method. The nurses analysis unit is 73 people. Data collection using questionnaire. The analysis technique used is descriptive technique by using frequency distribution Findings - Based on the results of the research using descriptive analysis, the results obtained that work environment in the quite conducive category, individual characteristics in the good category, and job stress in the quite high category.

Originality/value - The differences in this study located on an object research, time research, a measuring instrument, literature that used, the theory that is used and the results of the study.
\end{abstract}

Keywords: Work environment, Individual characteristics, Job stress

Article Type : Research Paper 


\section{PENDAHULUAN}

Pegawai adalah salah satu komponen terpenting yang dimiliki oleh perusahaan dalam upaya mempertahankan kelangsungan hidup, mengembangkan, kemampuan bersaing dan menghasilkan keuntungan (Senen, Sumiyati, \& Masharyono, 2017). Kinerja pegawai sangat penting dalam upaya perusahaan untuk mencapai bisnis tujuannya dan menjadi salah satu faktor utama keberhasilan suatu perusahaan (Senen \& Triananda, 2016). Kinerja pegawai yang rendah merupakan prioritas yang dihadapi oleh perusahaan saat ini, sehingga memaksimalkan kinerja menjadi tantangan utama dari setiap organisasi (Osa, 2014; Senen \& Triananda, 2016)

Stres kerja merupakan salah satu penyebab menurunnya kinerja pegawai dalam sebuah organisasi (Shivendra \& Kumar, 2016). Diidentifikasi bahwa sekitar $30 \%$ tenaga kerja di negara-negara maju menderita stres kerja, berbeda dengan negara berkembang yang memiliki tingkat stres kerja lebih tinggi tinggi (Hosseini et al., 2016). Kekhawatiran stress kerja antar pekerja di Amerika semakin meningkat, dilansir dalam majalah Fortune bahwa stress kerja sebagai salah satu masalah utama dalam dunia tenaga kerja di abad selanjutnya (Sager, 1994).

Penelitian mengenai stres kerja dilakukan diberbagai jenis perusahaan, baik itu perusahaan jasa atau perusahaan manufaktur. Negara India telah melakukan penelitian pada berbagai kelompok, seperti guru, sektor perbankan, sektor teknologi informasi (Shukla, Srivastava, \& Eldridge, 2016), dan perawat (Dagget, Molla, \& Belachew, 2016).

Stres kerja pada perawat merupakan salah satu permasalahan dalam manajemen sumber daya manusia di Rumah Sakit. Hasil survey nasional di Francis ditemukan bahwa presentase stres kerja sekitar $74 \%$ dialami oleh perawat (NIOSH, 2008). Penelitian di Uni Emirat Arab mengenai hubungan antara stres perawat dan faktor lingkungan pekerjaan pada 216 perawat yang dipilih dengan metode sampel acak pada perawat yang bekerja di lingkungan yang berbeda di rumah sakit Al-Zahra. Sebesar 44,4\% memiliki tingkat stres rendah, 55,1\% memiliki tingkat stres menengah, dan $0,5 \%$ memiliki tingkat stres tinggi (Mozhdeh, Sabet, Irani, Hajian, \& Malbousizade, 2008).

Di Indonesia yang memiliki jumlah pegawai kerja mencapai 120,4 juta orang pada Februari 2012, atau bertambah sebesar 1,0 juta orang dibanding Februari 2011, memiliki potensi kerugian yang sangat besar sebagai dampak dari stres kerja (Fitri, 2013). Penelitian yang dilakukan oleh Martina menyatakan bahwa 80 perawat yang bekerja diruang rawat inap RSPG Cisarua Bogor mengalami stress kerja pada tingkat sedang
$(86 \%)$. Perawat di rumah sakit Islam Yogyakarta PDHI diketahui mengalami stres kerja sedang dengan persentase $82,70 \%$. Perawat dengan tingkat stres yang sedang rata-rata masih dapat menyelesaikan pekerjaannya (Hariyono, Suryani, \& Wulandari, 1978). Hasil survey dari Persatuan Perawat Nasional Indonesia (PPNI) tahun 2006 sekitar 50,9\% perawat mengalami stress, sering pusing, lelah, tidak bisa beristirahat karena beban kerja terlalu tinggi dan menyita waktu, gaji rendah tanpa insentif yang memadai. Tingkat stress kerja berdasarkan lama kerja menunjukkan bahwa perawat dengan masa kerja 6 bulan sampai 3 tahun mempunyai tingkat stress kerja tinggi yaitu 12,5\% (Sumarto, Asfian, Munandar, \& Oleo, 2016).

Biasanya pekerja atau pegawai yang stres akan menunjukan perubahan perilaku. Perubahanperubahan ini di tempat kerja merupakan gejalagejala individu yang mengalami stres antara lain: (a) bekerja melewati batas kemampuan, (b) keterlambatan masuk kerja yang sering, (c) ketidakhadiran pekerjaan, (d) kesulitan membuat keputusan, (e) kesalahan yang sembrono, (f) kelalaian menyelesaikan masalah, (g) lupa akan janji yang telah dibuat dan kegalalan diri sendiri, (h) kesulitan berhubungan dengan orang lain, (i) kerisauan tentang kesalahan yang dibuat, (j) menunjukan gejala fisik seperti pada alat pencernaan, tekanan darah tinggi, radang kulit, radang pernapasan (Zainal et al. 2014: 316).

Tingginya tingkat stres kerja perawat akan merugikan Rumah Sakit tersebut. Konsenkuensi yang timbul dan bersifat tidak langsung adalah meningkatnya tingkat absensi, menurunnya tingkat produktivitas, dan toleransi, hingga turnover (Zainal et al. 2014: 317). Individu cenderung mengalami stres yang berhubungan dengan pekerjaan ketika ada persepsi ancaman dan ketidakmampuan untuk mengatasi masalah (Chetty, Coetzee, \& Ferreira, 2016).

Stres kerja muncul disebabkan oleh tiga sumber, yaitu pekerjaan, individu dan luar pekerjaan. Sumber intrinsik pada pekerjaan, peran di dalam organisasi, perkembangan karir, hubungan relasi ditempat kerja, struktur organisasi dan iklim kerja merupakan bagian dari sumber pekerjaan yang menjadikan stres kerja (Greenberg, 2002). Faktor-faktor penyebab stres kerja menurut Dwiyanti (2001) dikelompokkan menjadi 7 kelompok: 1) tidak adanya dukungan sosial, 2) tidak adanya kesempatan berpartisipasi dalam pembuatan keputusan di kantor, 3) pelecehan seksual, 4) kondisi lingkungan kerja, 5) manajemen yang tidak sehat, 6) tipe kepribadian, dan 7) peristiwa/pengalaman pribadi (Zainal et al. 2014: 311).

Lingkungan kerja diidentifikasi sebagai faktor terpenting yang mempengaruhi stres kerja 
pada perawat (Loo-See Beh, 2016). Lingkungan kerja dapat dibagi untuk 2 jenis lingkungan kerja fisik dan kerja sosial. Lingkungan kerja masyarakat adalah aspek psikologis bekerja dan peraturan kerja yang dapat mempengaruhi kepuasan kerja dan produktivitas (Purnama \& Pratama, 2016). Lingkungan kerja fisik yang semua keadaan bentuk fisik yang terdapat di sekitar tempat kerja yang dapat mempengaruhi karyawan, baik secara langsung maupun tidak langsung dan mempengaruhi karyawan dalam melaksanakan beban tugas pegawai (Masharyono, Sumiyati, \& Toyib, 2016). Lingkungan kerja sosial atau psikis dapat menciptakan produktifnya perawat dan dapat meningkatka keuntungan bagi organisasi (Pratama \& Purnama, 2016).

Faktor lain yang mempengaruhi terjadinya stres kerja adalah karakteristik individu. Karakteristik individu adalah reaksi-reaksi psikologis, fisiologis, dan individunya, mencakup ciri-ciri kepribadian yang khusus dan pola-pola perilaku yang didasarkan pada sikap, kebutuhan, nilai-nilai, pengalaman masa lalu, keadaan kehidupan dan kecakapan (Zainal et al., 2014: 316). Karakteristik individu merupakan faktor penting terjadinya hubungan dalam sebuah perusahaan. Adanya hubungan yang baik antara semua lapisan di perusahaan tersebut akan mempermudah karyawan untuk menjalankan tugasnya dengan baik (Juliandiny, Senen, \& Sumiyati, 2016), karena kemajuan suatu perusahaan ditentukan oleh kualitas sumber daya manusia yang dimilikinya (Senen \& Solihat, 2008).

Berdasarkan latar belakang masalah di atas, maka tujuan penelitian ini adalah untuk memperoleh hasil temuan mengenai: (1) gambaran lingkungan kerja, (2) gambaran karakteristik individu, dan (3) gambaran stres kerja kerja

\section{KAJIAN PUSTAKA}

Dalam usaha memenuhi kebutuhan hidupnya manusia memerlukan manusia lain. Tujuan dari usaha manusia akan lebih mudah diperoleh dengan cara bersama-sama daripada dengan sendiri saja. Organisasi merupakan suatu unit terkoordinasi yang terdiri setidaknya dua orang, berfungsi mencapai satu sasaran tertentu atau serangkaian sasaran (Zainal et al., 2014: 170). Menurut ahli lain mengatakan bahwa, organisasi adalah kelompok orang yang bekerja secara saling bergantung terhadap suatu tujuan (McShane \& Glinow, 2018).

Perilaku organisasi adalah suatu studi yang menyangkut aspek-aspek tingkah lau manusia dalam suatu kelompok tertentu (Zainal et al.,
2014: 171), sedangkan menurut McShane \& Glinow (2018) perilaku organisasi adalah studi tentang apa yang orang pikirkan, rasakan, dan lakukan di dalam dan di sekitar organisasi yang lebih memfokuskan pada perilaku karyawan, keputusan, persepsi, dan respons emosional.

Perilaku organisasi memiliki tiga jenis variabel (masukan, proses, dan keluaran) pada tiga level analisis (individu, kelompok, dan organisasi). Masukan (input) adalah variabel seperti kepribadian, struktur kelompok, dan budaya organisasi yang berujung pada proses. Proses pada level individu mencakup emosi dan suasana hati, motivasi, persepsi, serta pengambilan keputusan. Keluaran (output) pada level individu meliputi sikap dan stres, kinerja tugas, perilaku kewargaan, dan perilaku penarikan diri (Robbins \& Judge, 2015).

Menurut Robbins \& Judge (2015) bagian stuktur kelompok memunculkan beberapa elemen yang penting, salah satunya adalah lingkungan kerja lingkungan kerja merupakan salah satu faktor pendukung untuk meningkatkan kinerja di tempat kerja. Lingkungan kerja merupakan sebuah konsep yang luas yang mencakup 1) bagaimana pekerjaan diatur, 2) karakteristik kerjasama dan proses, 3) sifat kepemimpinan, dan 4) budaya organisasi (Trépanier, Fernet, Austin, \& Boudrias, 2016).

Lingkungan kerja didefinisikan sebagai suatu karakteristik nyata atau abstrak dari sebuah organisasi yang mencakup pengaturan fisik, komunikasi antarpribadi, upaya saling berkolaborasi, tingkat otonomi dan tingkat pemberdayaan yang berkaitan dengan struktur, proses, serta hasil dari organisasi (Bai et al., 2015). Lingkungan kerja adalah segala sesuatu yang berada disekitar pegawai yang dapat mempengaruhi mereka dalam melaksanakan tugas yang diberikan, selain itu lingkungan kerja menyebabkan seorang pegawai dapat menyesuaikan diri atau tidak terhadap lingkungan kerja (Guntoro, Hastuti, \& Nurtini, 2016). Lingkungan kerja perawat merupakan karakteristik organisasi kerja yang memfasilitasi atau membatasi praktik keperawatan yang profesional (Corchia et al., 2016). Lingkungan kerja perawat yang sehat didefinisikan sebagai tempat kerja aman, memberdayakan dan memuaskan, di mana semua staf perawatan kesehatan bekerja sungguh-sungguh untuk kesehatan yang optimal dan keselamatan (Dirik \& Intepeler, 2017).

Suwatno \& Priansa (2011: 163) mengemukakan dimensi dari lingkungan kerja sangat berpengaruh terhadap tinggi rendahnya stres pegawai yang terdiri atas lingkungan kerja fisik dan lingkungan kerja psikis. Lingkungan fisik adalah lingkungan yang berada disekitar 
pekerja itu sendiri, sedangkan lingkungan psikis adalah hal-hal yang menyangkut dengan hubungan sosial dan keorganisasian

Menurut Siagian (2006:63) untuk menciptakan lingkungan kerja yang baik ada beberapa hal yang harus diperhatikan yaitu, 1) bangunan tempat kerja, 2) ruang kerja yang lega, 3) ventilasi pertukaran udara, 4) tersedianya tempat-tempat ibadah keagamaan, dan 5) tersedianya sarana angkutan khusus maupun umum untuk karyawan nyaman dan mudah. Suwatno \& Priansa (2011: 163) mengemukakan secara umum lingkungan kerja terdiri dari dua faktor, yaitu lingkungan kerja fisik dan lingkungan kerja psikis.

Karakteristik individu merupakan bagian dari level perilaku individu. (Robbins \& Judge, 2015) menyatakan bagian perilaku individu ini seperti, karakteritik beragam individu, kepribadian, serta nilai-nilai yang dibentuk oleh kombinasi warisan genetik individu dan lingkungan dimasa kecil. Robbins dan Judge (2015) menjelaskan bahwa sebuah organisasi memiliki perbedaan karakteristik. Karakteristik dari masing-masing individu (personal) tersebut meliputi: ciri biografis (usia, jenis kelamin, status perkawinan, dan masa kerja), ciri kepribadian, nilai, sikap, persepsi dan tingkat kemampuan dasar yang akan mempengaruhi perilaku mereka ditempat kerja. Perilaku individu sebagai fungsi dari interaksi antara individu dengan lingkungannya. Sementara karakteristik individu akan dibawa memasuki lingkungan baru, yaitu organisasi atau lainnya (Zainal et al., 2014: 230)

Karakteristik individu merupakan keseluruhan kelakuan dan kemampuan yang ada pada individu sebagai hasil dari pembawaan lingkungannya. Karakteristik individu dapat diukur dengan sikap, minat, dan kebutuhan. Individu membawa nilai yang melekat dalam diri yang terbentuk oleh lingkungan dimana dia tinggal, nilai - nilai tersebutlah yang nantinya dibawa dalam situasi kerja (Moses, Astuti, \& Hakam, 2014). Karakteristik individu adalah ciri khas yang menunjukkan perbedaan seseorang tentang motivasi, inisiatif, kemampuan untuk tetap tegar menghadapi tugas sampai tuntas, memecahkan masalah atau bagaimana menyesuaikan perubahan yang terkait erat dengan lingkungan yang mempengaruhi kinerja individu (Abdul Rahman, 2013).

Menurut Miftah (2014) bahwa individu membawa beberapa karakteristik ke dalam tatanan organisasi, seperti: kemampuan, kepercayaan pribadi, pengharapan kebutuhan, dan pengalaman masa lalunya. Kategori-kategori dasar dari karakteristik individu meliputi kepribadian, sikap, persepsi dan kreativitas (Rosita \& Sariningtyas, 2016). Karakteristik individu yang mencirikan antara satu orang dengan orang lain berbeda adalah karena masingmasing individu memiliki potensi dan kebutuhan yang berbeda (Husien \& Hady, 2012).

Dimensi dari karakteristik individu terdiri atas keterampilan, pengalaman, pengetahuan, dan demografi individu (Gibson, Ivancevich, Donnelly, \& Konopaske, 2012: 146). Keterampilan merupakan kapasitas individu untuk melaksanakan berbagai tugas dalam pekerjaan tertentu. Pengalaman dapat diartikan juga sebagai memory episodic, yaitu memori yang menerima dan menyimpan peristiwa yang terjadi atau dialami individu pada waktu dan tempat tertentu, yang berfungsi sebagai referensi autobiografi. Pengetahuan mencerminkan kemampuan kognitif seorang karyawan berupa kemampuan untuk mengenal, memahami, menyadari dan menghayati suatu tugas/pekerjaan. Demografi individu meliputi, umur,asal-usul, dan jenis kelamin.

Menurut Robbins \& Judge (2015) Ada beberapa faktor dari karakteristik individu, antara lain, usia, jenis kelamin, status pernikahan, jumlah tanggungan, dan pengalaman kerja. Sedangkan menurut Beal et al., (2016) bahwa faktor-faktor karakteristik individu terdiri dari 1) umur, 2) jenis kelamin, 3) tingkat pendidikan, dan 4) masa kerja.

Perilaku organisasi dibagi tiga bagian pokok menjadi perilaku individu, perilaku kelompok dan perilaku organisasi. Stres kerja muncul dari perubahan organisasional dan manajemen stres yang merupakan salah satu bagian dalam perilaku organiasi (Robbins \& Judge, 2015). Perubahan organisasi dapat didefinisikan dari sudut pandang pengembangan organisasi, yang salah satu pendekatannya signifikan terhadap perubahan organisasi (Hornstein 2015: 294)

Stres kerja dapat didefinisikan sebagai tanggapan berbahaya fisik dan emosional yang terjadi ketika syarat pekerjaan tidak sesuai kemampuan, sumber daya, atau kebutuhan pekerja. Stres kerja dapat menyebabkan rendahnya kesehatan bahkan cedera (AzadMarzabadi \& Gholami Fesharaki, 2016). Stres kerja secara umum didefinisikan sebagai respon dari seorang individu terhadap ketegangan yang dihasilkan dari lingkungan kerja tertentu (Lambert, Hogan, \& Griffin, 2007). "Job stress is defined as a particular relation between the employed and his or her work environment" ini berarti bahwa stres kerja muncul disebabkan karena adanya hubungan antara pekerja dengan lingkungan kerjanya (Schaufeli \& Peeters, 2000), sejalan dengan teori yang dikemukakan oleh Schaufeli \& Peeters (2000) bahwa stres kerja merupakan pengalaman subjektif dari hasil interaksi lingkungan kerja yang objektif dan 
sumber daya pegawai. Stres kerja dapat diukur menggunakan beberapa dimensi, yaitu: beban kerja (workload), tekanan kerja (pressure), konflik (conflict), dan ambiguitas peran (role ambiguity) (Robbins \& Judge, 2015).

Luthans (2011) mengemukakan beberapa faktor yang dapat mempengaruhi stres kerja, yaitu 1) stressor ekstraorganisasi, 2) stressor organisasi, 3) stressor kelompok, dan 4) stressor individu. Stressor ekstraorganisasi adalah faktor penyebab stres yang berasal dari luar perusahaan yaitu mencakup, a) perubahan sosial, b) kesulitan menguasai globalisasi,dan c) dukungan keluarga. Stressor organisasi yaitu penyebab stres yang berasal dari organisasi itu sendiri. Sering kali perusahaan mengalami intervensi perubahan dalam strategi bisnis mereka untuk bersaing dengan perusahaan lain, maka ada beberapa akibat yang sering pula timbul ketika perusahaan mengalami intervensi, yaitu a) kebijakan atau peraturan pimpinan yang terlalu otoriter terhadap karyawan dan b) ketidakjelasan tugas. Stressor kelompok dapat di kategorikan menjadi dua area, yaitu a) rekan kerja yang tidak menyenangkan dan b) kurangnya kebersamaan dengan rekan kerja. Pada stressor individu terdapat kesepakatan mengenai dimensi situasi dan disposisi individu yang dapat mempengaruhi stress. Disposisi individu seperti pola kepribadian tipe A, kontrol personal. Faktor stres yang mempengaruhi seorang individu adalah beban kerja, terbatasnya waktu kerja dan peran ganda. Pola kepribadian karyawan saat mengalami stres kerja berbeda-beda

Berdasarkan penjelasan mengenai pengaruh lingkungan kerja dan karakteristik individu terhadap stres kerja, maka disusun sebuah paradigma pengaruh lingkungan kerja dan karakteristik indvidu terhadap stres kerja secara jelas digambarkan dalam Gambar 1 sebagai berikut:

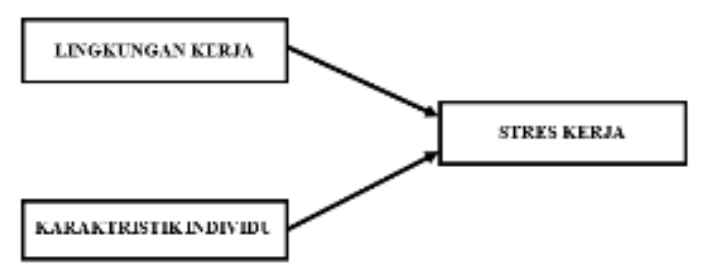

\section{GAMBAR 1 PARADIGMA PENELITIAN}

\section{METODE PENELITIAN}

Penelitian ini dilakukan untuk mengetahui pengaruh lingkungan kerja dan karakteristik individu terhadap stres kerja perawat Rumah Sakit Umum Avisena di Cimahi. Adapun yang menjadi objek penelitian sebagai variabel $\mathrm{X}$ atau variabel bebas (independent variabel) adalah lingkungan kerja dengan dimensinya yang mencakup lingkungan kerja fisik dan lingkungan kerja psikis. Serta karakteristik individu dengan dimensinya yang mencakup keterampilan, pengalaman, pengetahuan dan demografi individu.

Masalah penelitian yang merupakan variabel (Y) atau variabel terikat (dependent variabel) adalah stres kerja dengan dimensinya yang mencakup beban kerja, tekanan kerja, konflik kerja, dan ambiguitas peran.

Penelitian ini dilakukan di Rumah Sakit Umum Avisena yang berlokasi di Jl. Melong No. 170, Kelurahan Melong, Kecamatan Cimahi Selatan, Kota Cimahi, Indonesia. Adapun yang menjadi objek penelitian ini adalah tanggapan responden tentang lingkungan kerja dan karakteristik individu terhadap stres kerja. Sedangkan yang menjadi unit analisis adalah perawat Rumah Sakit Umum Avisena. Penelitian ini dilakukan dalam kurun waktu kurang dari satu tahun, maka pendekatan yang digunakan adalah metode cross sectional method, dimana penelitian ini dengan cara mempelajari objek dalam kurun waktu tertentu atau tidak berkesinambungan dalam jangka waktu panjang.

Berdasarkan tingkat penjelasan dan bidang penelitian, maka jenis penelitian ini adalah penelitian deskriptif dan verifikatif, dengan metode penelitian yang digunakan adalah explonatory survey. Populasi dalam penelitian ini adalah perawat Rumah Sakit Umum Avisena yang berjumlah 73 orang.

Teknik penarikan sampel yang digunakan dalam penelitian ini adalah teknik penelitian populasi atau sensus, karena sampel diambil dari seluruh populasi yang dinamakan sampel jenuh. Sampel jenuh yaitu teknik penentuan sampel bila semua anggota populasi digunakan sebagai sampel (Sugiyono, 2017: 85). Penelitian ini menggunakan teknik sampel jenuh, yaitu dengan mengambil seluruh jumlah perawat Rumah Sakit Umum Avisena Cimahi sebanyak 73 orang.

Secara statistik, hipotesis yang akan diuji dalam rangka pengambilan keputusan penerimaan atau penolakan hipotesis dapat dirumuskan sebagai berikut:

1. Hipotesis 1

$\mathrm{H}_{0}: \rho=0$, artinya gambaran lingkungan kerja diprediksi cukup tidak kondusif.

Ha $: \rho>0$, artinya gambaran lingkungan kerja diprediksi cukup kondusif.

2. Hipotesis 2

$\mathrm{H}_{0}: \rho=0$, artinya gambaran karakteristik individu diprediksi cukup buruk.

Ha : $\rho>0$, artinya artinya gambaran karakteristik individu diprediksi cukup baik.

3. $\mathrm{H}_{0}: \rho=0$, artinya gambaran stres kerja diprediksi cukup rendah. 
Ha $: \rho>0$, artinya gambaran stres kerja diprediksi cukup tinggi.

\section{HASIL PENELITIAN DAN PEMBAHASAN}

Lingkungan kerja didefinisikan sebagai suatu karakteristik nyata atau abstrak dari sebuah organisasi yang mencakup pengaturan fisik, komunikasi antarpribadi, upaya saling berkolaborasi, tingkat otonomi dan tingkat pemberdayaan yang berkaitan dengan struktur, proses, serta hasil dari organisasi (Bai et al., 2015). Menurut Sarode \& Shirsath (2016) lingkungan kerja menjadi keseluruhan alat perkakas dan bahan yang dihadapi sekitarnya di mana seseorang bekerja dengan metode kerjanya, serta pengaturan kerjanya baik untuk perseorangan maupun sebagai kelompok. Lingkungan kerja secara umum terdiri dari lingkungan kerja fisik dan lingkungan kerja psikis (Suwatno \& Priansa, 2011: 163).

Lingkungan kerja fisik sebagai kondisi tempat kerja karyawan bekerja yang mencakup: teknik penerangan, suhu udara, suara kebisingan, penggunaan warna, dan ruang gerak yang diperlukan (Mangkunegara, 2014: 105).

Menurut Mangkunegara (2014:105) mengungkapkan bahwa lingkungan kerja psikis adalah semua aspek fisik psikologis kerja dan peraturan kerja yang dapat mempengaruhi kepuasan kerja dan pencapaian produktivitas.

Berdasarkan hasil pengolahan data yang dilakukan melalui penyebaran angket pada perawat Rumah Sakit Umum Avisena di Cimahi, lingkungan kerja dapat diukur melalui perhitungan rata-rata dimensi dan perhitungan skor keseluruhan. Berikut ini dipaparkan hasil dari rekapitulasi perhitungan skor:

TABEL 1

\section{REKAPITULASI DIMENSI} LINGKUNGAN KERJA

\begin{tabular}{ccccc}
\hline No & Dimensi & Skor Ideal & Total Skor & $\%$ \\
\hline 1 & Lingkungan kerja fisik & 3.066 & 2.253 & 73,48 \\
2 & Lingkungan kerja psikis & 5.110 & 3.851 & 75,36 \\
& TOTAL & 8.176 & 6.104 & 74,66 \\
\hline
\end{tabular}

Berdasarkan Tabel 1 rekapitulasi dimensi lingkungan kerja skor tertinggi terdapat pada dimensi lingkungan kerja psikis dengan peroleh skor 3.851, termasuk kedalam kategori cukup kondusif $(75,36 \%)$. Dalam hal ini menunjukan lingkungan kerja psikis memiliki kemampuan yang baik. Lingkungan kerja yang mendukung termasuk sumber daya yang memadai, hubungan rekan yang baik, dan dukungan manajemen (Zhang et al., 2015). Adanya kenyamanan komunikasi antara pegawai dengan instruktur menunjukan bahwa adanya respon yang efektif terhadap pemenuhan harapan dalam proses pertukaran pesan dan yang diterjemahkan menjadi pengalaman yang menyenangkan dan memuaskan (Balakrishnan, 2013).

Sementara skor terendah terdapat pada dimensi lingkungan kerja fisik diperoleh skor 2.253, termasuk kedalam kategori cukup kondusif (73,48\%). Menurut Wilkinson et al. (2017) bahwa kenyamanan dan keamanan harus diperhatikan agar karyawan tetap berada dalam perusahaan, jika lingkungan kerja tidak terpenuhi sesuai dengan kebutuhan maka karyawan akan meninggalkan perusahaan. Karyawan yang memiliki kinerja tidak baik dapat dinilai dari lingkungan kerjanya yang mendukung atau tidak (Robbins \& Judge, 2015). Kualitas dan kuantitas kerja dihasilkan oleh karyawan yang dipengaruhi oleh lingkungan kantor, dan kondisi lingkungan yang buruk dapat menyebabkan produktivitas pegawai tidak efisien serta mengurangi kepuasan kerja mereka, yang pada gilirannya akan berdampak pada kesejahteraan finansial dari organisasi (Sarode \& Shirsath, 2016).

Secara keseluruhan variabel lingkungan kerja memperoleh skor 6.104, apabila di persentasekan kedalam skor ideal maka diperoleh persentase sebesar 74,66\%, dengan demikian variabel lingkungan kerja berada pada kategori cukup kondusif. Sedangkan dilihat dari garis kontinum yang telah dihitung adalah:

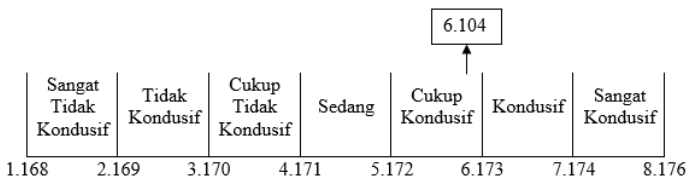

GAMBAR 2

GARIS KONTINUM VARIABEL LINGKUNGAN KERJA

Berdasarkan Gambar 2 pada nilai kontinum variabel lingkungan kerja yaitu 6.104 sesuai dengan data penelitian yaitu termasuk kedalam kategori cukup kondusif, dengan demikian dapat dikatakan bahwa lingkungan kerja di Rumah Sakit Umum Avisena di Cimahi dirasakan oleh perawat cukup kondusif.

Berdasarkan hasil penelitian dari angket yang disebar kepada 73 responden diketahui bahwa lingkungan kerja Rumah Sakit Umum Avisena di Cimahi mencapai skor 6.104 dari skor kriterium atau jumlah maksimal perolehan nilai responden terletak pada daerah 5.172 - 6.173, sehingga dapat dikatakan bahwa lingkungan kerja yang dimiliki oleh Rumah Sakit Umum Avisena di Cimahi telah diaplikasikan dengan cukup baik, namun lingkungan kerja tersebut perlu ditingkatkan lagi karena semua dimensi berada di bawah skor ideal. Kualitas dan kuantitas kerja dihasilkan oleh karyawan yang dipengaruhi oleh lingkungan kantor, dan kondisi lingkungan yang buruk dapat menyebabkan produktivitas pegawai tidak efisien serta mengurangi kepuasan kerja 
mereka, yang pada gilirannya akan berdampak pada kesejahteraan finansial dari organisasi (Sarode \& Shirsath, 2016)

Karakteristik individu adalah minat, sikap terhadap diri sendiri, pekerjaan, dan situasi pekerjaan, kebutuhan individual, kemampuan atau kompentensi, pengetahuan tentang pekerjaan dan emosi, suasana hati, perasaan keyakinan dan nilai-nilai (Ardana, Komang, 2008). Menurut Miftah (2014:37) berkaitan dengan karakteristik individu, bahwa individu membawa kedalam tatanan organisasi, kemampuan, kepercayaan pribadi, pengharapan kebutuhan dan pengalaman masa lalunya. Ini semua adalah karakteristik yang dimiliki individu dan karakteristik ini akan memasuki suatu lingkungan baru, yakni organisasi. Gibson, et al. (2012) mengemukakan bahwa dimensi dari karakteristik individu terdiri atas keterampilan, pengalaman, pengetahuan, dan demografi individu.

Keterampilan (skill) merupakan kemampuan untuk mengoperasikan pekerjaan secara mudah dan cermat (Anisman-Razin \& Saguy, 2016). Sedangkan menurut Borella, et al (2017) istilah terampil juga diartikan sebagai suatu perbuatan atau tugas, dan sebagai indikator dari suatu tingkat kemahiran.

Pengalaman dapat dijadikan sebagai dasar untuk menjadi lebih baik dari sebelumnya dan sebagai sumber pengetahuan untuk memperoleh suatu kebenaran. Pengalaman yang pernah didapat seseorang akan mempengaruhi kematangan seseorang dalam berpikir (Notoatmodjo, 2007).

Pengetahuan atau kognitif merupakan domain yang sangat penting dalam membentuk tindakan seseorang (Notoatmodjo, 2007). Menurut Sam \& Chatwin, (2016) pengetahuan mencakup akan hal-hal yang pernah dipelajari dan disimpan dalam ingatan.

Berdasarkan hasil pengolahan data yang dilakukan melalui penyebaran angket pada perawat Rumah Sakit Umum Avisena di Cimahi, karakteristik individu dapat diukur melalui perhitungan rata-rata dimensi dan perhitungan skor keseluruhan. Berikut ini dipaparkan hasil dari rekapitulasi perhitungan skor:

\section{TABEL 2}

REKAPITULASI DIMENSI KARAKTERISTIK INDIVIDU

\begin{tabular}{clccc}
\hline No & Dimensi & Skor Ideal & Total Skor & $\mathbf{\%}$ \\
\hline 1 & Ketcrampilan & 4.088 & 3.111 & 76,10 \\
2 & Pengalaman & 3.066 & 2.333 & 76,09 \\
3 & Pengetahuan & 2.044 & 1.553 & 75,98 \\
& TOTAL & $\mathbf{9 . 1 9 8}$ & $\mathbf{6 . 9 9 7}$ & $\mathbf{7 6 , 0 7}$ \\
\hline
\end{tabular}

Berdasarkan Tabel 2 rekapitulasi dimensi karakteristik individu, skor tertinggi terdapat pada dimensi keterampilan dengan peroleh skor 3.111, termasuk dalam kategori baik $(76,10 \%)$. Dalam hal ini menunjukan keterampilan yang dimiliki oleh perawat Rumah Sakit Avisena di Cimahi dapat dikatakan baik. Keterampilan yang dimiliki ini dapat menunjang kinerja dan kemajuan perusahaan. Keteramailan merupakan kapasitas individu untuk melaksanakan berbagai tugas dalam pekerjaan tertentu (Gibson et al., 2012).

Sementara skor terendah terdapat pada dimensi pengetahuan dengan perolehan skor 1.553 , termasuk kategori baik $(75,98 \%)$. Dalam hal ini kurangnya pengetahuan yang dimiliki oleh perawat Rumah Sakit Umum Avisena di Cimahi. Pengetahuan mencerminkan kemampuan kognitif seorang karyawan berupa kemampuan untuk mengenal, memahami, menyadari dan menghayati suatu tugas/pekerjaan (Gibson et al., 2012).

Secara keseluruhan variabel karakteristik individu memperoleh skor 6.997, apabila di persentasekan kedalam skor ideal maka diperoleh persentase sebesar 76,07\%, dengan demikian variabel karakteristik individu berada pada kategori baik. Sedangkan dilihat dari garis kontinum yang telah dihitung adalah:

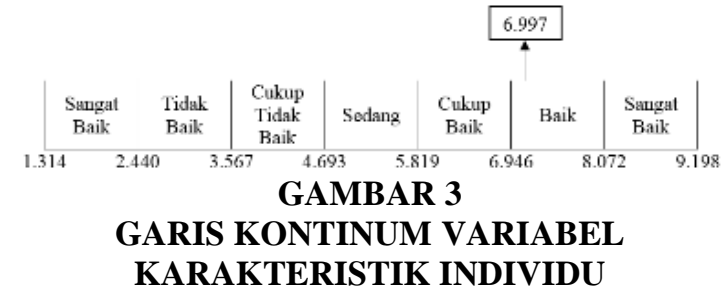

Berdasarkan Gambar 3 pada nilai kontinum variabel karakteristik individu yaitu 6.997 sesuai dengan data penelitian yaitu termasuk kedalam kategori baik, dengan demikian dapat dikatakan bahwa karakteristik individu perawat Rumah Sakit Umum Avisena di Cimahi sudah baik.

Berdasarkan hasil penelitian dari angket yang disebar kepada 73 responden diketahui bahwa karakteristik individu perawat Rumah Sakit Umum Avisena di Cimahi mencapai skor 6.997 dari skor kriterium atau jumlah maksimal perolehan nilai responden terletak pada daerah 6.946 - 8.072, sehingga dapat dikatakan bahwa karakteristik individu yang dimiliki oleh RSU Avisena di Cimahi telah diaplikasikan dengan baik, namun karakteristik individu tersebut perlu ditingkatkan lagi, karena semua dimensi berada di bawah skor ideal. Karakteristik individu mencirikan antara satu orang dengan orang lain yang berbeda karena masing-masing individu memiliki potensi dan kebutuhan yang berbeda. Karakteristik individu sendiri dapat diartikan sebagai karakteristik pribadi yang menyangkut umur, jenis kelamin, dan status perkawinan yang objektif dan mudah diperoleh dari catatan pribadi (Sagna \& Sparks, 2016)

Menurut Robbins \& Judge (2015) bahwa stres sebagai suatu kondisi dinamis, dimana 
individu dihadapkan pada kesempatan, hambatan dan keinginan dan hasil yang diperoleh sangatlah penting tetapi tidak dapat dipastikan. Stres kerja merupakan kondisi ketegangan yang berpengaruh terhadap emosi, jalan pikiran, dan kondisi fisik seseorang (Siagian, 2006: 300). Stres kerja dapat diukur menggunakan beberapa dimensi, yaitu: beban kerja (workload), tekanan kerja (pressure), konflik (conflict), dan ambiguitas peran (role ambiguity) (Robbins \& Judge, 2015).

Beban kerja dapat diberikan menjadi beban kerja kuantitatif, bila tugas yang diberikan terlalu banyak atau terlalu sedikit untuk diselesaikan, dan beban kerja kualitatif, bila dirasakan tidak mampu menyelesaikan tugas akibat tugasnya terlalu sulit atau terlalu mudah sehingga membosankan Sedarmayanti (2011:21).

Tekanan kerja adalah sebagai rangsangan lingkungan yaitu kekuatan yang ditimpakan atas individu, sebagai respon fisik ataupun psikologis individu atas kekuatan lingkungan tersebut, dan sebagai interaksi antara kedua peristiwa tersebut (Banerjee \& Mehta, 2016).

Menurut Robbins \& Judge (2015) konflik adalah suatu proses yang dimulai satu pihak merasakan bahwa pihak lain telah mempengaruhi secara negatif atau akan segera mempengaruhi secara negatif pihak lain.

Ambiguitas peran terjadi ketika individu tidak memperoleh kejelasan menganai tuga-tugas dari pekerjaannya atau tidak tahu apa yang seharusnya diikerjakan (Luthans, 2011).

Berdasarkan hasil pengolahan data yang dilakukan melalui penyebaran angket pada perawat Rumah Sakit Umum Avisena di Cimahi, stres kerja dapat diukur melalui perhitungan ratarata dimensi dan perhitungan skor keseluruhan. Berikut ini dipaparkan hasil dari rekapitulasi perhitungan skor:

\section{TABEL 4 \\ REKAPITULASI DIMENSI STRES KERJA}

\begin{tabular}{clccc}
\hline No & Dimensi & Skor Ideal & Total Skor & \% \\
\hline 1 & Beban kerja & 2.044 & 1.550 & 75,83 \\
2 & Tekanan kerja & 3.066 & 2.138 & 69,73 \\
3 & Konflik kerja & 2.555 & 1.884 & 73,74 \\
4 & Ambiguitas peran & 3.066 & 2.010 & 65,56 \\
& TOTAL & $\mathbf{1 0 . 7 3 1}$ & $\mathbf{7 . 5 8 2}$ & $\mathbf{7 0 , 6 6}$ \\
\hline
\end{tabular}

Berdasarkan Tabel 2 rekapitulasi dimensi stres kerja, skor tertinggi terdapat pada dimensi beban kerja dengan peroleh skor 1.550 , termasuk dalam kategori cukup tinggi $(75,83, \%)$. Beban kerja dapat didefinisikan sebagai keengganan untuk datang bekerja dan perasaan tekanan konstan (yaitu tidak ada upaya yang cukup) disertai dengan gejala stres fisiologis, psikologis, dan perilaku umum (Syazreena Azmi, Asiah Md. Shahid, \& Alwi, 2016). Beban kerja yang berlebihan merupakan sumber stres di tempat kerja dan kelelahan emosional (Karatepe, 2013).
Tuntutan yang lebih tinggi di tempat kerja menguras sumber daya berharga seperti waktu, energi, dan emosi, yang penting untuk memenuhi kewajiban keluarga (Diane \& Tremblay, 2016).

Sementara skor terendah terdapat pada dimensi ambiguitas peran dengan skor 2.010, termasuk kedalam kategori cukup tinggi $(65,56 \%)$. Ambiguitas peran dapat muncul disebabkan kurangnya informasi atau karena tidak adanya indormasi sama sekali atau informasinya tidak disampaikan kepada individu mengenai pekerjaannya (Yasa, 2017) Menurut Singh (1998) menyatakan bahwa ketika pekerja mengalami ambiguitas peran atau ketidakjelasan peran, disanalah mereka tidak mengetahui dengan jelas bagaimana mereka menjalankan pekerjaan secara efektif maka dalam bekerja mereka cenderung tidak efisien dan tidak terarah sehingga tingkat kinerja yang dialami pekerja akan menurun.

Secara keseluruhan variabel stres kerja memperoleh skor 7.582, apabila di persentasekan kedalam skor ideal maka diperoleh persentase sebesar $70,66 \%$, dengan demikian variabel stres kerja berada pada kategori cukup tinggi. Sedangkan dilihat dari garis kontinum yang telah dihitung adalah:

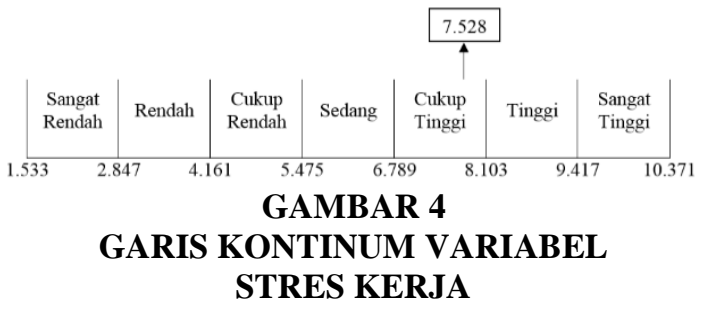

Berdasarkan Gambar 4 pada nilai kontinum variabel stres kerja yaitu 7.528 sesuai dengan data penelitian yaitu termasuk kedalam kategori cukup tinggi, dengan demikian dapat dikatakan bahwa stres kerja perawat Rumah Sakit Umum Avisena di Cimahi cukup tinggi.

Berdasarkan hasil penelitian dari angket yang disebar kepada 73 responden diketahui bahwa stres kerja perawat Rumah Sakit Umum Avisena di Cimahi mencapai skor 7.528 dari skor kriterium atau jumlah maksimal perolehan nilai responden terletak pada daerah 6.789 - 8.103, sehingga dapat dikatakan bahwa stres kerja yang dialami oleh perawat RSU Avisena di Cimahi masih cukups tinggi. Hal ini menunjukkan beban kerja, tekanan kerja, konflik kerja dan ambiguitas peran di RSU Avisena di Cimahi dikatakan cukup tinggi, langkah yang harus dilakukan oleh pihak Rumah Sakit Umum Avisena adalah dengan meningkatkan kualitas lingkungan kerja (Sutherland \& Cooper, 1992).

Berdasarkan penelitian diatas menyatakan bahwa semakin kondusif lingkungan kerja, maka semakin rendah tingkat stres kerja perawat 
Rumah Sakit Umum Avisena di Cimahi. Selain itu, semakin baik karakteristik individu perawat, maka semakin rendah pula tingkat stres kerja yang akan dialami oleh perawat Rumah Sakit Umum Avisena di Cimahi.

\section{DAFTAR PUSTAKA}

Abdul Rahman, A. (2013). Psikologi Sosial: Integrasi Pengetahuan Wahyu dan Pengetahuan Empirik. Jakarta: Rajawali Pers.

Anisman-Razin, M., \& Saguy, T. (2016). Reactions to tokenism: The role of individual characteristics in shaping responses to token decisions. European Journal of Social Psychology, 46(6), 716731. https://doi.org/10.1002/ejsp.2215

Ardana, Komang, D. (2008). Perilaku Keorganisasian (Pertama). Yogyakarta: Graha Ilmu.

Azad-Marzabadi, E., \& Gholami Fesharaki, M. (2016). Job Stress and Related Factors Among Iranian Male Staff Using a Path Analysis Model. Iranian Red Crescent Medical Journal, 16(3), 24-26. https://doi.org/10.5812/ircmj.34314

Bai, J., Zhang, Q., Wang, Y., Yu, L. P., Pei, X. B., Cheng, L., \& Hsu, L. (2015). Work environment for Chinese nurses in different types of ICUs: A multisite cross-sectional survey. Journal of Nursing Management, 23(4), 498-509. https://doi.org/10.1111/jonm.12163

Balakrishnan, C. (2013). Impact of Internal Communication on Employee Engagement - A Study at Delhi International Airport. International Journal of Scientific and Research Publications, 3(8), 1-13. https://doi.org/ISSN 2250-3153

Banerjee, S., \& Mehta, P. (2016). Determining the Antecedents of Job Stress and Their Impact on Job Performance: A Study Among Faculty Members. 8 The IUP Journal of Organizational Behavior, xv(2), 2016.

Beal, S. J., Riddle, I. K., Kichler, J. C., Duncan, A., Houchen, A., Casnellie, L., ... Corathers, S. D. (2016). The Associations of Chronic Condition Type and Individual Characteristics With Transition Readiness. Academic Pediatrics, 16(7), 660-667. https://doi.org/10.1016/j.acap.2016.06.007

Borella, E., Carbone, E., Pastore, M., Beni, R. De, \& Carretti, B. (2017). Working memory training for healthy older adults: The role of individual characteristics in explianing short- and long-term gains. Frontiers in Human Neuroscience, 11(99). https://doi.org/10.3389/fnhum.2017.00099
Chetty, P. J., Coetzee, M., \& Ferreira, N. (2016). Sources of job stress and cognitive receptivity to change: the moderating role of job embeddedness. South African Journal of Psychology, 46(1), 101-113. https://doi.org/10.1177/0081246315591308

Corchia, C., Fanelli, S., Gagliardi, L., Bellu, R., Zangrandi, A., Persico, A., \& Zanini, R. (2016). Work environment, volume of activity and staffing in neonatal intensive care units in Italy: results of the SONARnurse study. Italian Journal of Pediatrics, 42, 34. https://doi.org/10.1186/s13052-0160247-6

Dagget, T., Molla, A., \& Belachew, T. (2016). Job related stress among nurses working in Jimma Zone public hospitals, South West Ethiopia: a cross sectional study. $B M C$ Nursing, $\quad 15(1), \quad 39$. https://doi.org/10.1186/s12912-016-0158-2

Diane, S. M., \& Tremblay, G. (2016). Workload, generic and work - family specific social supports and job stress : mediating role of work-family and family-work conflict. International Journal of Contemporary Hospitality Management $\cdot, 28(8)$.

Dirik, H. F., \& Intepeler, S. S. (2017). The work environment and empowerment as predictors of patient safety culture in Turkey. Journal of Nursing Management, 25(4), 256-265. https://doi.org/10.1111/jonm.12458

Fitri, A. M. (2013). Analisis Faktor-Faktor yang Berhubungan dengan Kejadian Stres Kerja pada Karyawab Bank (Studi pada Karyawan Bank BMT). Jurnal Kesehatan Masyarakat 2013, 2(1).

Gibson, J. L., Ivancevich, J. M., Donnelly, J. H., \& Konopaske, R. (2012). Organizations: Behavior, Structure, Processes (14th ed.). New York: McGraw-Hill.

Greenberg, J. S. (2002). Comprehensive Stress Management (7th ed.). New York: McGraw-Hill Companies.

Guntoro, B., Hastuti, D. W., \& Nurtini, S. (2016). The Relationship Between Leadership Type , Work Motivation , Training of Employee , and Physical Work Environment Toward Employee' s Performance of Fastfood Company in Yogyakarta Indonesia, 5(1), $18-25$.

Hariyono, W., Suryani, D., \& Wulandari, Y. (1978). Hubungan Antara Beban Kerja, Stres Kerja Dan Tingkat Konflik Dengan Kelelahan Kerja Perawat Di Rumah Sakit Islam Yogyakarta Pdhi Kota Yogyakarta. Kesmas, 3(3), 186-197.

Hornstein, H. (2015). The integration of project management and organizational change 
management is now a necessity. International Journal of Project Management, 33, 291-298.

Hosseini, S., Habibi, E., Barakat, S., Ahanchi, N., Fooladvand, M., \& Khorasani, E. (2016). Investigating the relationship of mental health with job stress and burnout in workers of metal industries. International Journal of Educational and Psychological Researches, 2(2), 111. https://doi.org/10.4103/2395-2296.178867

Husien, N. M., \& Hady, A. (2012). Pengaruh Lingkungan Kerja Dan Karakteristik Individu Terhadap Kepuasan Kerja Karyawan Hotel Melati Di Kecamatan Banjarmasin Tengah. Jurnal Manajemen Dan Akutansi, 13(11), 73-84.

Juliandiny, T., Senen, S. H., \& Sumiyati. (2016). Kompensasi Serta Motivasi Kerja pada Kinerja Keperawatan Kontrak. Journal of Business Management Education, 1(2), 8190.

Karatepe, O. (2013). The effects of work overload and work-family conflict on job embeddedness and job performance The mediation of emotional exhaustion. International Journal of Contemporary Hospitality Management, 25(4), 614-634.

Lambert, E. G., Hogan, N. L., \& Griffin, M. L. (2007). The impact of distributive and procedural justice on correctional staff job stress, job satisfaction, and organizational commitment. Journal of Criminal Justice, 35(6), 644-656. https://doi.org/10.1016/j.jcrimjus.2007.09.0 01

Loo-See Beh. (2016). Job Stress and Coping Mechanisms among Nursing Staff in Public Health Services Leap-Han Loo. International Journal of Academic Research in Business and Social Sciences, 6(5), 131-176. https://doi.org/10.6007/IJARBSS/v6i5/2164

Luthans, F. (2011). Organizational Behavior: An Evidence-Based Approach (12th ed.). New York: McGraw-Hill/Irwin.

Mangkunegara, A. A. A. P. (2014). Manajemen Sumber Daya. Manusia Perusahaan. Bandung: Remaja Rosdakarya.

Masharyono, Sumiyati, \& Toyib. (2016). Physical Work Environment Effect on Employee Productivity of Textile Industry. Atlantis Press, 15, 630-632.

McShane, S. L., \& Glinow, M. A. Von. (2018a). Organizational behavior: emerging knowledge, global reality (Eight). New York: McGraw-Hill Education.

McShane, S. L., \& Glinow, M. A. Von. (2018b).
Organizational Behavior: Eemerging Knowledge. Global Reality (8th ed.). New York: McGraw-Hill Education. https://doi.org/10.12737/4477

Miftah, T. (2014). Perilaku Organisasi, Konsep Dasar dan Aplikasinya. Jakarta: Rajawali Pers.

Moses, R. M., Astuti, E. S., \& Hakam, M. S. (2014). Pengaruh Karakteristik Individu Dan Karakteristik Pekerjaan Terhadap Prestasi Kerja Karyawan ( studi pada karyawan PT. Inti Bara Mandiri Tuban ), 12(1), 1-10.

Mozhdeh, S., Sabet, B., Irani, M., Hajian, E., \& Malbousizade, M. (2008). Relationship between nurse's stress and environmental occupational factors. Iran $J$ Nurs Midwifery, 13(1), 1-5.

NIOSH. (2008). Exposure to Stress Occupational Hazards in Hospital. NIOSH.

Notoatmodjo, S. (2007). Pendidikan dan Perilaku Kesehatan (Kedua). Jakarta: PT. Rineka Cipta.

Osa, I. G. M. (2014). Incentives Motivates Employee's On Organizational Performance. Global Journal of Arts Humanities and Social Sciences, 2(7).

Pratama, K. F., \& Purnama, R. (2016). The Effect of Social Work Environment on Employee Productivity in Manufacturing Company in Indonesia. Atlantis Press, 15, 574-575.

Purnama, R., \& Pratama, K. F. (2016). The Influence of Social Work Environment on Employee Productivity in Manufacturing in Indonesia. Atlantis Press, 15, 649-652.

Robbins, S. P., \& Judge, T. A. (2015). Organizational Behavior (16th ed.). New Jersey: Pearson.

Rosita, E., \& Sariningtyas, W. (2016). Analisis Karakteristik Individu Dan Motivasi Intrinsik Terhadap Komitmen Organisasi Dengan Kepuasan Kerja Sebagai Variabel Intervening (Studi pada PDAM Tirta Mulia Kabupaten Pemalang). Jurnal Ilmiah UNTAG Semarang, 5(1), 55-72.

Sager, J. K. (1994). A structural model depicting salespeople's job stress. Journal of the Academy of Marketing Science, 22(1), 7484.

https://doi.org/10.1177/0092070394221007

Sagna, M. L., \& Sparks, P. J. (2016). Institutional Birth in Uganda: The Interplay of Individual Characteristics, Physical Accessibility, and Social Context. Women's Reproductive Health, 3(1), 30-44. https://doi.org/10.1080/23293691.2016.115 0134

Sam, K. M., \& Chatwin, C. R. (2016). Adoption of Near Field Communication in Hotel 
Industry Based on Risk Perspectives and Individual Characteristics. IEEE IEEM, 257-261.

Sarode, A. P., \& Shirsath, M. (2016). The Factors Affecting Employee Work Environment \& It's Relation with Employee Productivity. International Journal of Science and Research (IJSR), 3(11).

Schaufeli, W. B., \& Peeters, M. C. W. (2000). Job Stress and Burnout among Correctional Officers: A Literature Review. International Journal of Stress Management. https://doi.org/10.1023/A:1009514731657

Sedarmayanti. (2011). Manajemen Sumber Daya Manusia, Reformasi Birokrasi dan Manajemen Pegawai Negeri Sipil (Kelima). Bandung: PT Rafika Aditama.

Senen, S. H., \& Solihat, S. (2008). Pengaruh Motivasi Kerja dan Kemampuan Kerja Karyawan pada PT. Safilindo Permata. Strategic, 7(14), 1-15.

Senen, S. H., Sumiyati, \& Masharyono. (2017). Employee Performance Assessment System Design Based on Competence. Innovation of Vacational Technology Education, 2(8), 68-70.

Senen, S. H., \& Triananda, N. (2016). The Employee Performance Influenced by Communication: a Study of BUMD in Indonesia. Atlantis Press, 15, 596-598.

Shivendra, D., \& Kumar, M. M. (2016). a Study of Job Satisfaction and Job Stress Among Physical Education Teachers Working in Government, Semi-Government and Private Schools. International Journal of Sports Sciences \& Fitness, 6(1), 89-99. Retrieved from

http://spot.lib.auburn.edu/login?url=http://s earch.ebscohost.com/login.aspx?direct=true $\& \mathrm{db}=$ sph \&AN=114041012\&site=ehost-live

Shukla, A., Srivastava, R., \& Eldridge, D. (2016). Development of short questionnaire to measure an extended set of role expectation conflict, coworker support and work-life balance: The new job stress scale. Cogent Business \& Management, 3(1), 1. https://doi.org/10.1080/23311975.2015.113 4034

Siagian, S. P. (2006). Manajemen Sumber Daya Manusia (Edisi I). Jakarta: Bumi Aksara.

Singh, R. S. (1998). Plant Diseases (Seventh Ed). New Delhi: Oxford \& IBH Publishing CO. PVT. LTD.

Sumarto, I., Asfian, P., Munandar, S., \& Oleo, U. H. (2016). Perbedaan Stress Kerja di Tinjau dari Shift Kerja Pagi Siang dan Malam pada Perawat di Rumah Sakit Umum Daerah Kota Kendari Tahun 2016 Fakultas
Kesehatan Masyarakat, 1-7.

Sutherland, V. J., \& Cooper, C. L. (1992). Job stress, satisfaction, and mental health among general practitioners before and after introduction of new contract. $B M J$ (Clinical Research Ed.), 304(6841), 15451548. Retrieved from http://www.pubmedcentral.nih.gov/articlere nder.fcgi ?artid=1882446\&tool=pmcentrez \&rendertype $=$ abstract

Suwatno, \& Priansa, D. J. (2011). Manajemen SDM dalam Organisasi Publik dan Bisnis. Bandung: Alfabeta.

Syazreena Azmi, F., Asiah Md. Shahid, S., \& Alwi, A. (2016). The Relationship between Job Stress and Front-liners' Job Performance in a Shared Service Center in Malaysia. International Journal of Social Science and Humanity, 6(7), 510-513. https://doi.org/10.7763/IJSSH.2016.V6.701

Trépanier, S. G., Fernet, C., Austin, S., \& Boudrias, V. (2016). Work environment antecedents of bullying: A review and integrative model applied to registered nurses. International Journal of Nursing Studies, 55(October), 85-97. https://doi.org/10.1016/j.ijnurstu.2015.10.0 01

Wilkinson, A., Redman, T., \& Dundon, T. (2017). Contemporary Human Resource Management. United Kingdom: Pearson.

Yasa, I. W. M. (2017). Pengaruh Konflik Peran dan Ambiguitas Peran Terhadap Kinerja Pegawai Melalui Mediasi Stres Kerja Pada Dinas Kesehatan Kota Bali. Jurnal Ekonomi \& Bisnis, 4(1), 38-57.

Zainal, V. R., Hadad, M. D., \& Ramly, M. (2014). Kepemimpinan dan Perilaku Organisasi. Depok: PT. RajaGrafindo Persada.

Zhang, L., You, L., Liu, K., Zheng, J., Fang, J., Lu, M., ... Bu, X. (2015). The Association of Chinese Hospital Work Environment with Nurse Burnout, Job Satisfaction, and Intention to Leave. NIH Public Access Author Manuscript, 62(2), 128-137. https://doi.org/10.1016/j.outlook.2013.10.0 10.The 